\title{
New insect-disease complex strikes Southland trees
}

RIVERSIDE, Calif. - UC Riverside scientists have identified a new insect-disease complex that is threatening avocado, coast live oak, box elder and other trees in Southern California. The complex includes a new shot hole borer and a symbiotic Fusarium species, which causes branch dieback. The same beetle and fungus have also been found in Israel, where the complex has caused severe damage to avocado trees since 2009.

Entomologists led by Richard Stouthamer proposed the name polyphagous shot hole borer (PSHB) for the tiny insect, an ambrosia beetle. Smaller than a sesame seed (the female is 0.1 inch), the insect was

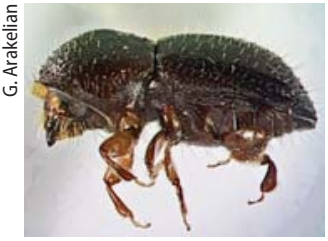

Polyphagous shot hole borer earlier misidentified as tea shot hole borer. Subsequent DNA sequencing by UCR scientists distinguished the insect as a different, potentially new, species.

After it bores into a tree, the insect deposits the fungus, which causes branch dieback

and eventual death of the tree. The yet unnamed Fusarium sp. was identified by Akif Eskalen, UC Riverside Cooperative Extension plant pathologist.

Eskalen has linked the insect-disease complex to the branch dieback and general decline of several avocado and landscape trees found in February and
March this year in Los Angeles and Orange County residential neighborhoods.

The insect and fungus have a symbiotic relationship, Eskalen says. "When the female beetle burrows into the tree, it lays its eggs in galleries; the eggs develop into larvae, which feed on the fungus," he explains. "At the same time, the fungus attacks the vascular tissue of the tree, disturbing water and nutrient flow, and causing branch dieback and - if not stopped - the tree's death."

If infected branches are cut off early enough, trees can be saved. It is important that growers and homeowners not move infested avocado wood out of the infested area.

If you suspect you have found the PSHB or seen symptoms of Fusarium dieback in your avocado grove or in other host plants, please contact your local farm advisor, county agricultural commissioner, or UC Riverside's Eskalen at akif.eskalen@ucr.edu or (951) 827-3499. - Iqbal Pittalwalla and Janet White

\section{TO OUR READERS:}

\section{Managing editor Byron moves on}

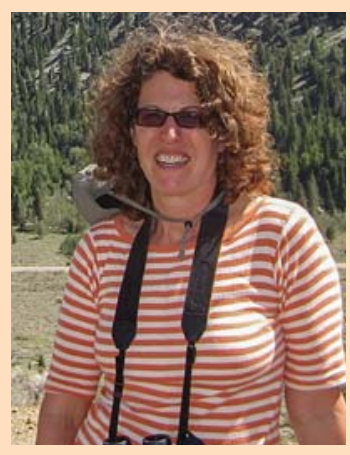

Janet Byron
After 13-plus years with California Agriculture journal, managing editor Janet Byron left in September to pursue a new career opportunity.

Byron was first hired in June 1999 as a special editor to help develop the journal's "Future in Focus: 2000-2025" editions, which were published in 2000. She

became managing editor in February 2001.

When Byron started, California Agriculture was mailing out paper reviews, scanning slides and posting abstracts on its website.

"We have undergone a lot of changes to bring the journal into the digital age, but our commitment to publishing high-quality, peer-reviewed research in a beautiful, easily accessible format has never wavered," she said.

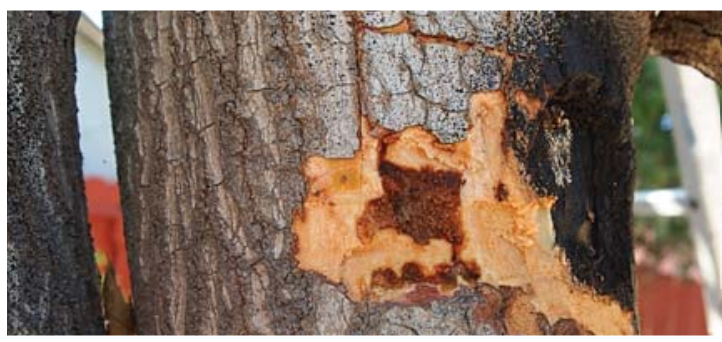

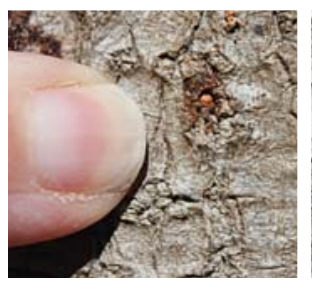

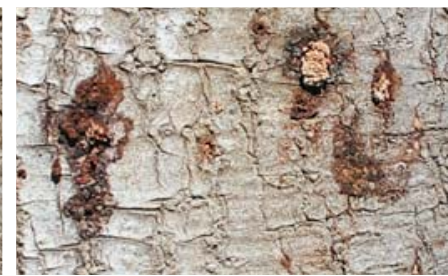

Symptoms in avocado include the appearance of white, powdery exudate in association with a single beetle exit hole on the bark of the trunk and main branches of the tree. This exudate could be dry, or it could appear as a wet discoloration.
"Janet has been an unfailing source of creativity and inspiration in the challenging task of delivering sound science to a lay audience," said Janet White, executive editor. "She responds to challenges with optimism and new ideas. She has been a key collaborator in the team effort to make the journal widely accessible on the Web - and will be greatly missed."

During her tenure, the journal won numerous awards from the Association of Communication Excellence in Agriculture, Natural Resources, and Life and Human Sciences (ACE) for editing, writing, and technical and electronic publications.

"I have enjoyed working with everyone in ANR, especially the hundreds of scientists who have shared their research results and patiently submitted to editing over the years," Byron said.

Byron's new position is senior communications specialist for the Kaiser Permanente Division of Research in Oakland, where she will help disseminate medical research results. She can be reached at janetbyron@att.net.

\section{Correction}

In a letter

from Dilipsinh

M. Gaekwar

published in the July-September 2012 issue, the year that Justin Smith Morrill began serving in Congress was incorrect. The correct year is 1855 , not 1885 . 